\title{
Lack of clean water exacerbates cholera outbreak in Haiti
}

$\mathrm{E}$ mergency medical workers in Haiti say acute water shortages are inflaming the cholera epidemic, while political unrest is affecting the water distribution network, which is resulting in more cholera cases and compromising capacity to treat the disease.

At a very minimum, water delivery trucks should be given special status and be allowed to pass through roadblocks and blockades which have become common in the wake of political protests following the disputed results of the Nov. 28, 2010, national elections, says Guillaume Le Duc, program manager for three cholera clinics operated by the Alliance for International Medical Action, a Paris-based nongovernmental organization supported by the European Community.

"During a cholera epidemic such as what we see in Haiti today, water trucks should be treated just like ambulances," he argues.

"Granting access to water is a vital priority to fight cholera," adds Le Duc, who says about 60 litres of clean water per patient daily are required to treat cholera.

Le Duc says a significant spike in the number of cholera cases presenting at the Alliance clinics was largely triggered by restricted access to clean water - almost all of which in Haiti is transported by road - during the political unrest.

Haiti's water supply is extremely fragile, Le Duc says, adding that treating the cholera outbreak has been difficult because of the unavailability of clean water, medical supplies and qualified medical staff.

As of Dec. 10, 2010, some 104918 Haitians had contracted cholera, according to the Haitian health ministry. About half of those were admitted to hospital and 2359 have died. But the United States Centers for Disease Control, which also says that water scarcity is a profound concern, says the number of cholera cases and deaths "likely are underreported" (www.cdc.gov/mmwr).

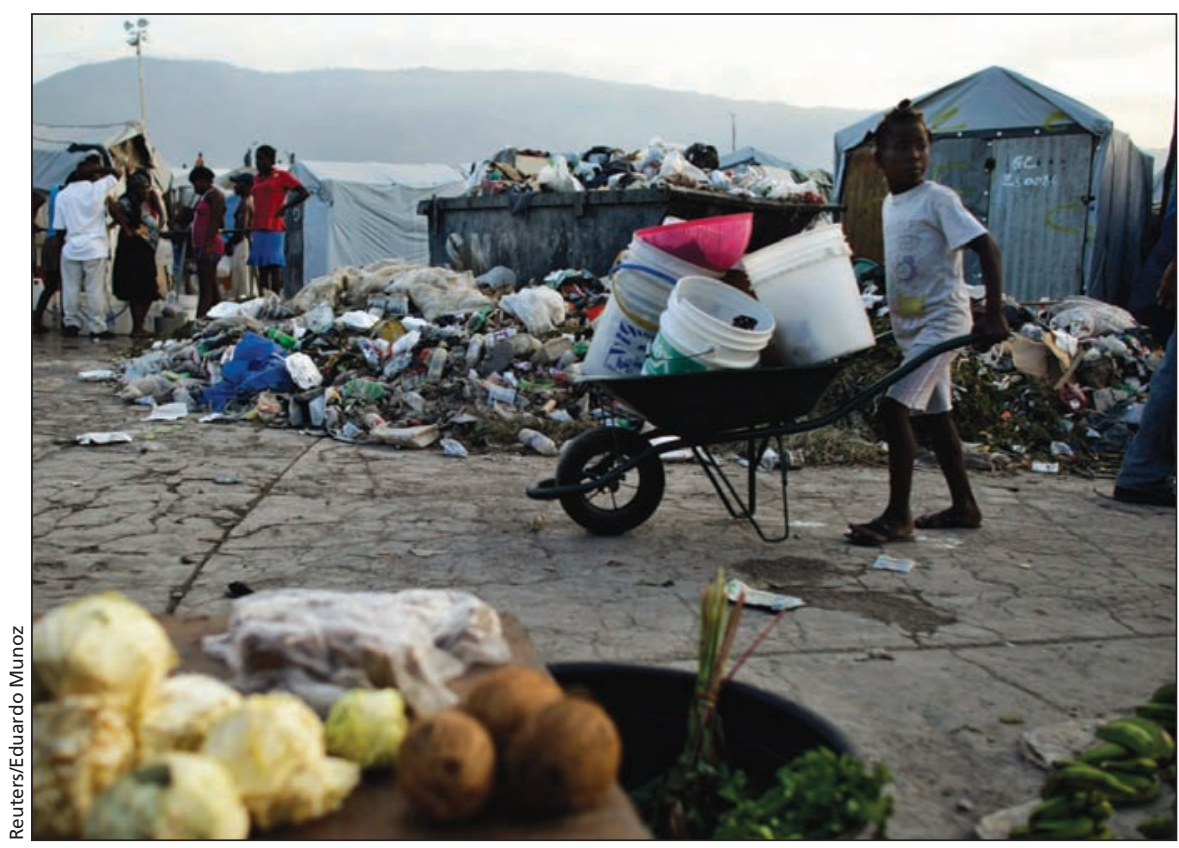

A Haitian girl pulls a wheelbarrow with buckets to collect water in a camp for internally displaced persons in Port-au-Prince in late November 2010.

Haiti's water woes have long been documented. As early as 2002, the country was ranked last among 147 nations in a Water Poverty Index produced by the Washington, DC-based environmental think tank, the World Resources Institute (http://earthtrends .wri.org/text/water-resources/variable $-1299 . \mathrm{html})$.

Le Duc says the 120 beds in Alliance clinics reached full capacity shortly after the election, when road blockages at the country's international airport prevented the movement of water, medical supplies and staff. Two planeloads of UNICEF supplies destined for cholera treatment centres had to be redirected to neighbouring Santo Domingo, according to UNICEF officials.

"We treated about 300 cases in the first three weeks after the epidemic began in November," Le Duc says. "Last week, we treated the same number." On average, about five patients had required oral rehydration solution (ORS) before the election but "on Dec. 15 , we had 49 cases requiring ORS," Le Duc says.
Transporting clean water in Portau-Prince has been a challenge since the election, says Gregory Bulit, coordinator for Solidarités International, a Paris-based nongovernmental organization, which, along with the Alliance, operates 11 water chlorination depots and nine ambulances in Haiti. "The blockages in the city paralysed our efforts to provide about 645000 litres of clean water daily, as well as in cleaning latrines and disinfection."

Bulit adds that the next stages in the electoral process pose new risks. "More blockades which again cut the water supply for hours or days will have dramatic consequences," he says, adding that keeping the water supply flowing will be a central priority for health care providers.

The Pan American Health Organization said in its most recent Health Cluster Bulletin that violence and instability since the elections "has had a detrimental effect on the fight against the cholera epidemic" (http://new.paho.org/disasters /index.php?option=com_docman\&task =doc_view\&gid=1608). 
Kristalina Geogieva, the European Union's Humanitarian Affairs commissioner, also warned in a press statement that political insecurity in Haiti "is jeopardising the efforts to fight cholera"
(http://europa.eu/rapid/pressReleases Action.do?reference=SPEECH/10/751 \&format $=$ HTML\&aged $=0 \&$ language $=$ EN\&guiLanguage $=e n)$. Mortality rates and the number of infected are likely to rise dramatically, she added. - Paul Christopher Webster, Toronto, Ont.

CMAJ 2011. DOI:10.1503/cmaj.109-3764 